Review Article

\title{
Impact of Physical Activity on the Psychological Health of the Elderly
}

\author{
María Antonia Parra-Rizo \\ Department of Health Psychology, Miguel Hernández University of Elche, Alicante, Spain \\ Email address: \\ maria.parrar@umh.es
}

\section{To cite this article:}

María Antonia Parra-Rizo. Impact of Physical Activity on the Psychological Health of the Elderly. Psychology and Behavioral Sciences. Vol. 7, No. 4, 2018, pp. 77-81. doi: 10.11648/j.pbs.20180704.11

Received: September 4, 2018; Accepted: November 12, 2018; Published: December 14, 2018

\begin{abstract}
Life expectancy and longevity present a great and urgent challenge due to the increase of population older than 65 years. This circumstance generates some high scientific, health and economic demands for facing the future ahead. Prevention of noncommunicable diseases related to population aging, aims to improve physical and psychological quality of life and consequently it has been implemented as a main measure of health policies. In this respect, the practice of physical activity and its effects on emotional variables is considered of great interest in this significant population as a preventive health step. Therefore, the aim of this paper is to describe the variables studied in relation with the practice of physical activity. For this purpose, a search was carried out in ScienceDirect, SportDiscus and Pubmed using as keywords "physical activity", "aging", "emotion" and "health"; limited to a time interval between 2007 and 2018. As a result of this search, a significant amount of publications regarding the benefits of depression, anxiety and stress in aging were found. However, attention is now being paid to the benefits of physical activity like reinforcement of positive states such as greater well-being and good mood. In conclusion, in the present work the studies related to the benefits of physical activity are examined in order to know its impact on the psychological well-being. The data suggest that the greatest benefit is provided by a medium intensity aerobic exercise, of between 30 and 60 minutes, practiced twice a week. Future studies should explore the benefits of physical exercise in psychological variables through a longitudinal design in order to verify a slowdown in the effects of aging.
\end{abstract}

Keywords: Physical Activity, Aging, Positive Emotion, Health, Intensity

\section{Introduction}

The increased ageing of the population, which is related to a greater life expectancy and improvements in health care, has generated a scientific challenge [1] becoming a highly relevant issue to be considered in both fields: that of healthcare and that of economics. In this line, longevity is part of a baseline survey that takes into account the quality of life and healthy habits, such as the practice of physical activity and positive emotional management, which enhance the quality of life of the elderly during their lives. Aging population involves future consequences and an important impact in society due to the growing demand in terms of health prevention which is generating a need for scientific, health and economic studies.

The demographics representation of the elderly population will be around 15 million people over 65 years of age by the year 2060 [2] and this will represent $35.6 \%$ of the Spanish population [2]. According to the Organization for Economic Cooperation and Development [2], this situation reflects a great sociodemographic change in every respect since it will be the elderly population who will represent half of the population of some OECD countries and EU members. This situation is a consequence of the socio-health improvements offered in terms of prevention and promotion of health, as well as education and socioeconomic improvements and new policies taken over the years [3]. In this way, the study of aging is a fundamental issue to research in order to achieve healthy aging.

In this line, it is necessary to observe the aging standards [4] On the other hand, and due to global life expectancy, reducing institutionalization and improving the quality of life of the elderly are both life standards considered essential in order to achieve the well-being of this population [5]. 
To that end, as a dynamic process, the most important factors that affect the process of aging are the ones related with the behaviour and with the lifestyle [3]. In addition, among these factors should be considered as well, the personal or individual conditions such as social circumstances, health and individual physics [6].

In relation to this theoretical framework, one of the ways to promote healthy aging is through the practice of physical activity. Furthermore, there are numerous publications informing about the benefits of sports in the elderly [7].

However, debate in relation to this topic can be found in the literature. On one side, some authors relate the practice of physical exercise with the prevention of diseases. On the other side, other authors consider exercise as the most important "polypill" to preserve physical and mental general health [8]. Nevertheless, many of them show study deficiencies in their methodology, design or in the objective studied. That is to say, there are studies which have focused their attention on the cognitive field and the maintenance of memory skills [9, 10], while others have paid attention to the improvement of strength and agility [11], others have shown interest in the pathological perspective of the elderly, such as dementia or Alzheimer's disease [12]. Some of the studies have made comparisons between the practice and non-practice of exercise in relation to self-esteem, depression and health [13, 14]. There are also studies that have evaluated the influence of physical practice on well-being [15], quality of life [16], and satisfaction [17].

Very few studies can be found regarding other types of research profiles in the elderly. In particular, some of them have focused on the practice of physical activity and well-being as tools that can enhance the quality of life.

In relation to this, and considering the school of thought of the positive psychology, the importance of well-being in the development and improvement of health and / or illness is highlighted [18]. This way of thinking implies that there is a positive state in every human being, such as a psychological well-being, which is often understood and interpreted as a subjective well-being.

This concept of psychological well-being allows many variables to indicate the appearance of this positive state. As example of these variables are the following: self-esteem, quality of life, perceived health, satisfaction with life, and the absence of psychological problems. In this sense, the scientific evidence indicates that physical activity has important benefits at the psychological level.

The objective of this work is to review the literature in order to identify the intensity of physical exercise that can improve the well-being of people in the aging process and for that purpose the variables studied in relation to the practice of physical activity have to be described. As a conclusion of the above considerations, the present work aims to show what has been studied up to now by reviewing the published evidence and then establishing future intervention programs that contemplate aging in an integral way.

\section{Methods}

A review of studies about the impact of physical activity on some emotional variables in the life of the elderly was carried out. For this, the ScienceDirect, SportDiscus and Pubmed databases were used looking for information of the last 10 years. In this search the descriptors used were "physical activity", "aging", "positive emotion" and "health". From all the articles found in the different databases a total of 18 studies which were published in different scientific journals were selected.

The following inclusion criteria used in the abstract and full text were the following: The inclusion criteria were: a) Studies that were scientific articles, b) with any kind of methodology, c) without age or sex limitations, d) with access to the complete text, e) written in Spanish and English, f) studies that included the relationship between physical activity and psychological health of the elderly, g) published after 2007 and that set their population survey on older adults.

As exclusion criteria, the following items were established: a) all non-scientific articles were eliminated; including editorial notes b) publications dated in 2007 and earlier, c) articles whose population under study were older adults institutionalized or dependent.

Although 57 publications were found, 14 published works were discarded firstly and another 21 references had to be eliminated as well, as there was no full text access and were not intrinsically related to the elderly. In the end, a total of 18 studies which are shown in the results section, were included for this review.

\section{Results}

After a thorough analysis of the selected publications was made, a great diversity of variables related to the practice of physical activity and aging were observed. The final outcome consists in a review of the most relevant publications on this subject. The results of the literature review are presented below in the following table 1 .

Table 1. Description of articles about physical activity and emotions in adults.

\begin{tabular}{|c|c|c|c|}
\hline Study & Shows & Objective & Conclusion \\
\hline Garcia, et al. 2018 & 184 Adults & $\begin{array}{l}\text { Analyze differences in self-esteem between practitioners and } \\
\text { non-practitioners. }\end{array}$ & Better self-esteem in practitioners. \\
\hline Guillén et al. 2018 & 111 Adults & $\begin{array}{l}\text { To assess the incidence of physical activity in the improvement of } \\
\text { depression and well-being. }\end{array}$ & Improvements in depression. \\
\hline Moral et al. 2018 & 168 Adults & $\begin{array}{l}\text { Analyze the impact of physical activity on self-esteem and } \\
\text { dependency level. }\end{array}$ & $\begin{array}{l}\text { Practitioners of physical activity better benefits } \\
\text { than sedentary and less dependence. }\end{array}$ \\
\hline Shiun et al. 2018 & 45 Adults & Explore the effects of a program of physical exercise, & Benefits in the areas studied. \\
\hline
\end{tabular}




\begin{tabular}{|c|c|c|c|}
\hline Study & Shows & Objective & Conclusion \\
\hline Awick et al. 2017 & 247 Adults & $\begin{array}{l}\text { functionality and psychological health and spiritual well-being. } \\
\text { Evaluate how changes in intensity influence quality of life. }\end{array}$ & $\begin{array}{l}\text { Intensity decreases distress, which in turn } \\
\text { improves the quality of life. }\end{array}$ \\
\hline Herrera et al. 2017 & 46 Adults & $\begin{array}{l}\text { Know the effect of physical activity on perceived health and } \\
\text { physical condition of older adults. }\end{array}$ & Improvements in mental health. \\
\hline Guillén et al. 2016 & 150 Adults & $\begin{array}{l}\text { Analyze the relationship of exercise in well-being, and its relation } \\
\text { to strength and optimism. }\end{array}$ & Improvements in optimism and hope. \\
\hline Orozco et al. 2016 & 32 Adults & $\begin{array}{l}\text { Describe psychological and cognitive characteristics of women } \\
\text { practicing Tai Chi Chuan Yang and non-practitioners. }\end{array}$ & $\begin{array}{l}\text { Better cognitive performance. There are no } \\
\text { improvements in depression or anxiety. }\end{array}$ \\
\hline Santana 2016 & 37Adults & $\begin{array}{l}\text { Analyze the influence of physical activity on personal } \\
\text { satisfaction. }\end{array}$ & $\begin{array}{l}\text { Practitioners showed greater satisfaction with life } \\
\text { and well-being. }\end{array}$ \\
\hline Villareal et al. 2016 & 20 Adults & Determine the effect of a Pilates-based program on mood. & $\begin{array}{l}\text { Decreased negative affects and favoured positive } \\
\text { ones in older adults. }\end{array}$ \\
\hline García et al. 2014 & 104 Adults & $\begin{array}{l}\text { Explore the happiness of people over } 65 \text {, as well as the } \\
\text { relationship that physical activity has with it. }\end{array}$ & $\begin{array}{l}\text { Physical activity as a source of happiness compared } \\
\text { to sedentary people. }\end{array}$ \\
\hline De Juanas et al. 2013 & 328 Adults & $\begin{array}{l}\text { Analyze the influence of perceived health status and healthy } \\
\text { habits. }\end{array}$ & $\begin{array}{l}\text { Perceived health status and good habits such as } \\
\text { regular exercise influence how older adults feel } \\
\text { about themselves, favouring greater well-being. }\end{array}$ \\
\hline García et al. 2013 & 184 Adults & $\begin{array}{l}\text { Analyze differences in self-esteem between older practicing and } \\
\text { non-practicing practitioners. }\end{array}$ & $\begin{array}{l}\text { Older people who exercise at least twice a week } \\
\text { have better self-esteem than sedentary people. }\end{array}$ \\
\hline Serrano et al. 2013 & 246 Adults & $\begin{array}{l}\text { Analyze the relationships of quantity and type of physical activity } \\
\text { with fitness, quality of life and moods. }\end{array}$ & $\begin{array}{l}\text { Organized physical activity presents better mood } \\
\text { and perception of quality of life. }\end{array}$ \\
\hline Montero et al. 2011 & 63 Adults & Assess the relationship between aerobic exercise and mood states. & Increases in vigour, well-being and less fatigue. \\
\hline Arruza et al. 2008 & $\begin{array}{l}1008 \\
\text { Adults }\end{array}$ & $\begin{array}{l}\text { To know the relationship between the duration of the exercise and } \\
\text { the perception of the physical and psychological state in the adult } \\
\text { population. }\end{array}$ & $\begin{array}{l}\text { The duration of physical activity is related to } \\
\text { physical condition and well-being. }\end{array}$ \\
\hline
\end{tabular}

\section{Discussion}

The objective of this work was to review several scientific publications based on the incidence of the practice of physical activity in the psychological health of older adults. The review confirms the diversity of psychological variables that have been studied. Nevertheless, the most important variable studied in the literature reviewed seems to be the benefit on psychological well-being.

As it has been said previously, the literature on this subject shows a great variety of studies in a way that makes it difficult to delimit the search. On one hand, the improvement of life satisfaction that positively affects the psychological well-being of people who practice physical exercise it has been highlighted recently [19]. On the other hand, it should not be ignore the discussion with the other related variables such as the incidence on the improvement of self-esteem [20], depression or negative states including anxiety or dependence $[14-15,21]$ or the improvement in the cognitive ability to generate favourable situations or thoughts as a consequence of physical activity [22].

However, the reviewed literature indicates improvements in psychological variables that are highlighted and have been further studied, such as psychological well-being after the practice of aerobic exercise in older practicing women [23]. Nevertheless, the literature focuses extensively on studying improvements in depression rates, better mental health and psychological well-being, but in this case without reference to the type of exercise $[15,24,25]$.

On the other hand, the reviewed studies pay great attention to the extent of the exercise. In this regard, several studies that include physical activity programs propose duration of less than 30 minutes of exercise in order to observe improvements in indices such as well-being [26]. While other studies indicate that the greater psychological benefits are obtained after 45 to 60 minutes per session of exercise twice a week, this practice also reflects improvements at a physical and psychological level such as the reduction of depression and anxiety, the increase in the quality of life, and the enhancement of psychological well-being [27].

Regarding the intensity of the practice, it is suggested that doing low-to-moderate intensity activities and its gradual increase, improves the physical aptitudes of the older people reducing at the same time stress [26]. In the same line, physical activity of moderate intensity is related to lower levels of alexithymia and to the achievement of lower rates of depression and anxiety as well as raising the perception of health status [21].

Although less studied in the field of aging, the incidence of physical activity in happiness stands out [16]. Recent studies $[28,29]$ talk about the positive impact of physical activity. In these surveys, the above-mentioned authors revealed specifically that the practice of non-aerobic physical exercise improves psychological health by reducing negative effects. 


\section{Conclusions}

The reviewed data indicate that there has been an improvement in the accuracy of the nomenclatures regarding physical activity and well-being. It has also show the necessity of delimitation in order to achieve a better search. As it has been explained above, the different types of samples, instruments that vary according to the study, the treatment made of the word "physical activity" and "well-being" or the type of design may be cause of inaccuracy of the results on this subject. Even sociocultural differences between different geographic regions, yet from the same country, could cause variability in the results that if not taken into account, could lead to erroneous conclusions.

It is important to mention the limitations found when reviewing the bibliography due to the lack of a clear and unique concept regarding physical activity and physical exercise. The absence of this unequivocal concept is a handicap when it comes to making the bibliographic search. The same happens when the search is about well-being and moods.

This review is interesting since it highlights some of the studies found in relation to this topic. The results obtained show that there are more studies based on variables that represent negative effects such as depression, anxiety and stress, than studies based on positive effects such as happiness There are also fewer studies that treat the positive psychological benefits in older adults of doing from 30 to 60 minutes of moderate intensity physical exercise twice a week. Nor are there enough studies that take into account the social or leisure need of the older adult to develop the activity and therefore the psychological benefits are not observed in the studied variables.

In order to establish future lines of research, it would be interesting to specifically determine the degree of physical intensity from which the well-being of the elderly improves. In this sense, [30] it should be noted that the relationship between physical activity and happiness in the elderly has not been studied sufficiently.

This work shows the influence that physical activity has on some emotional variables considered important for the well-being of the elderly. The conclusions of the study lead the way towards new research proposals where the positive effects that also take place in the aging process should be studied. Additionally, after the critical evaluation of the present review, the study of physical activity it has been proved to be a gap or inconsistency found in the literature that hampers the advance in this research topic.

Finally, this review should clarify issues of improvement concerning this topic as well as serve as a guide for future investigations to examine the aging process.

\section{References}

[1] Shankar, A., Bjorn, S. B. y Steptoe, A. (2015). Longitudinal associations between social connections and subjective wellbeing in the English Longitudinal Study of Ageing. Psychology \& Health, 30(6), 686-698.
[2] OECD y European Commission (2013). A good life in old age? Monitoring and improving quality in long-term care. Paris: OECD Publishing.

[3] Fernández-Ballesteros, R., Robine, J. M., Walker, A. y Kalache, A. (2013). Active aging: A global goal. Current Gerontology and Geriatrics Research. Doi: 10.1155/2013/298012.

[4] Cuenca-Amigo, M. y San Salvador del Valle, R. (2016). La importancia del ocio como base para un envejecimiento activo y satisfactorio. Revista de Psicología del Deporte, 25(2), 79-84.

[5] Onunkwor, O. F., Al-Dubai, S. A., George, P. P., Arokiasany, J., Yadav, H., Barva, A. y Shuaibu, H. O. (2016). A cross sectional study on quality of life among the elderly in non-governmental organizations elderly homes in Kuala Lumpur. Health and quality of life outcomes, 12, 6 .

[6] Santacreu, M., Bustillos, A. y Fernández-Ballesteros, R. (2016). Multidimensional/ Multisystems/ Multinature Indicators of Quality of Life: Cross-Cultural Evidence from Mexico and Spain. Social Indicators Research, 126(2), 467-482.

[7] Nilsen, C., Agahi, N. \& Shaw, B. (2018). Does the association between leisure activities and survival in old age differ by living arrangement. Journal of Epidemiology \& Community Health, 72, 1-6.

[8] Taylor, B. A. \& Pescatello, L. S.(2016). For the love it: Affective experiences that may increase physical activity participation among older adults. Social Science \& Medicine, 161, 61-63.

[9] Albuquerque, A. P. A., Borges-Silva, F., Gomez da Silva, E., Pinto, A. \& Dantas, E. (2017). Physical activity: Relationship to quality of life and memory in older people. Science \& Sports, 32(5), 259-265.

[10] Sánchez-González, J. L., Calvo-Arenillas, J. L. \& SánchezRodríguez, J. L. (2018). Efectos del ejercicio físico moderado sobre la cognición en adultos mayores de 60 años. Revista de Neurología, 66, 230-236.

[11] Pastor, D., Carbonell, L. \& Cervelló, E. (2017). Six months of exercise programa twice a week seems to be not enought to improve cognitive function in older people. European Journal of Human Movement, 39, 116-127.

[12] Pedroso, R. V., Cancela, J. M., Ayán, C., Stein, A. M., Fuzaro, G., Costa, J. L. R... \& Santos-Galduroz, R. F. (2018). Effects of physical exercise on the p300 of elderly with Alzheimer's disease, 15(6), 403-410.

[13] García, A. J. y Troyano, Y. (2013). Percepción de autoestima en personas mayores que realizan o no actividad física-deportiva. Escritos de Psicología, 2(6), 35-41.

[14] Moral, J., Orgaz, D., López, S., Amatria, M. y Maneiro, R. (2018). Influence of physical activity on self-esteem and risk of dependence in active and sedentary elderly people. Anales de Psicología, 1(34), 162-166.

[15] Guillén, L., Bueno, E., Gutiérrez, M. y Guerra, J. (2018). Programa de actividad física y su incidencia en la depresión y bienestar subjetivo de adultos mayores. Retos, 33, 14-19.

[16] Awick, E., Ehlers, D., Aguiñaga, S., Daugherty, A., Kramer, A. y McAuley, E. (2017). Effects of a randomized exercise trial on physical activity, psychological distress and quality of life in older adults. General Hospital Psychiatry, 49, 44-50. 
[17] Santana, A. (2016). Influencia de la actividad física en el bienestar psicológico del mayor. International Journal of Development and Educational Psychology, 2, 301-306.

[18] Vázquez, C., Hervás, G., Rahona, J. J. y Gómez, D. (2009). Bienestar psicológico y salud: Aportaciones desde la Psicología Positiva. Anuario de Psicología Clínica y de la Salud, 5, 15-28.

[19] Santana, A. (2016). Influencia de la actividad física en el bienestar psicológico del mayor. International Journal of Development and Educational Psychology, 2, 301-306.

[20] García, A. J. y Troyano, Y. (2013). Percepción de autoestima en personas mayores que realizan o no actividad física-deportiva. Escritos de Psicología, 2(6), 35-41.

[21] Medina, I., Romero, R. P., Gálvez, P., Moreno, N., Sánchez, E., Cuesta, J. S. ... Barón, F. J. (2016). Alexitimia y depresión en mayores que practican actividad física dirigida. Revista Iberoamericana de Ciencias de la Actividad Física y el Deporte, $5(3), 36-48$.

[22] De Juanas, A., Limón, M. R. y Navarro, E. (2013). Análisis del bienestar psicológico, estado de salud percibido y calidad de vida en personas adultas mayores. Pedagogía Social. Revista Interuniversitaria, 22, 153-168.

[23] Montero, P. J. y Baena, A. (2011). Efectos del ejercicio aeróbico sobre los estados de ánimo en mujeres mayores. Retos, 20, 43-47.

[24] Herrera, E., Pablos, A., Chiva-Bartoll, O. y Pablos, C. (2017).
Efectos de la Actividad Física en la Salud Percibida y Condición Física de los Adultos Mayores. Journal of Sport and Health Research, 9(1), 27-40.

[25] Orozco, G., Anaya, M., Santiago, J. y García, M. (2016). Cognición, actividades de la vida diaria y variables psicológicas en mujeres adultas mayores practicantes de Tai Chi Chuan (Yang). Retos, 30, 222-225.

[26] Arruza, J. A., Arribas, S., Gil, L., Irazusta, S., Romero, S. y Cecchinni, J. A. (2008). Repercusiones de la duración de la actividad físico-deportiva sobre el bienestar psicológico. Revista Internacional de Medicina y Ciencias de la Actividad Física y del Deporte, 30(8), 171-183.

[27] Villareal, M., Moncada, J., Gallegos, J. y Ruiz, F. (2016). El efecto de un programa de ejercicios basado en Pilates sobre el estado de ánimo en adultos mayores Mexicanos. Retos, 30, 106-109.

[28] Silva, R. y Mayán, J. M. (2016). Beneficios psicológicos de un programa proactivo de ejercicio físico para personas mayores. Escritos de Psicología, 1(9), 24-32.

[29] Shiun, P., Tish, M., Oh, B. y Funk, M. (2018). Physical and psychological effects of Qigong exercise in community-dwelling older adults: An exploratory study. Geriatric Nursing, 39, 88-94.

[30] García, M., Bohórquez, R. y Lorenzo, M. (2014). La implicación en la actividad física como fuente de felicidad en personas mayores. European Journal of Investigation in Health, Psychology and Education, 1(4), 19-30. 